Multimedia Appendix 1

Screenshot 1 'Welcome'

Introduction movie

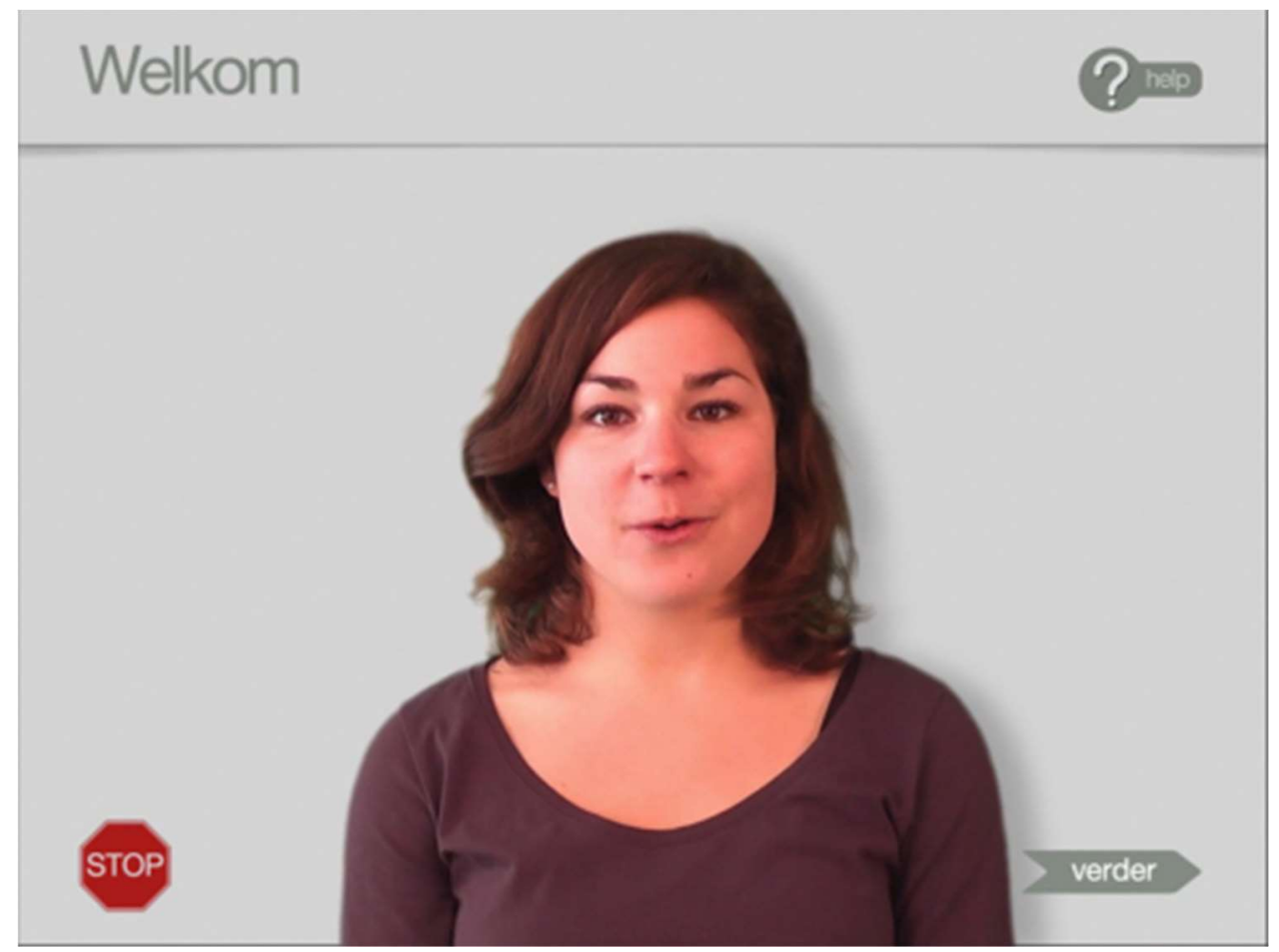

Screenshot 2 'Pain'

Question 1: "Do you have pain? Yes/No"

Pijn

Heeft u pijn?

$\mathrm{Ja}$

Nee 
Screenshot 3 'Location of the health problem'

Question 2: "Tap on the location of your health problem. You can tap on multiple locations."

\section{Plaats klachten}

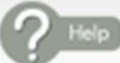

Druk op de plaats waar u klachten heeft.

U kunt op meerdere plaatsen drukken.
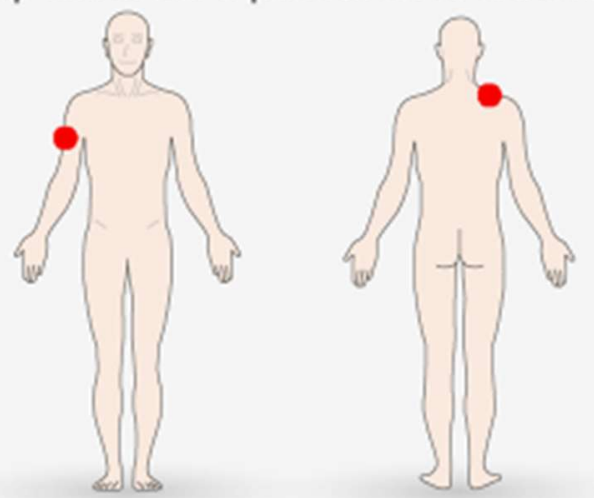

Screenshot 4 'pain severity'

Question 3: "This is the location of your pain.

Rate the severity of your pain on the scale below."

\section{Ernst pijn}



U heeft hier pijn.

Geef op de balk aan hoeveel pijn u hier heeft.

\begin{tabular}{ll|l|l|l|l|l|l|l|l|l|l|}
\hline 0 & 1 & 2 & 3 & 4 & 5 & 6 & 7 & 8 & 9 & 10 \\
\hline
\end{tabular}


Screenshot 5 'Overview location of the health problems'

Overview answers question 1-3:

"This is the location of your health problems."

\section{Plaats klachten}

U heeft hier klachten
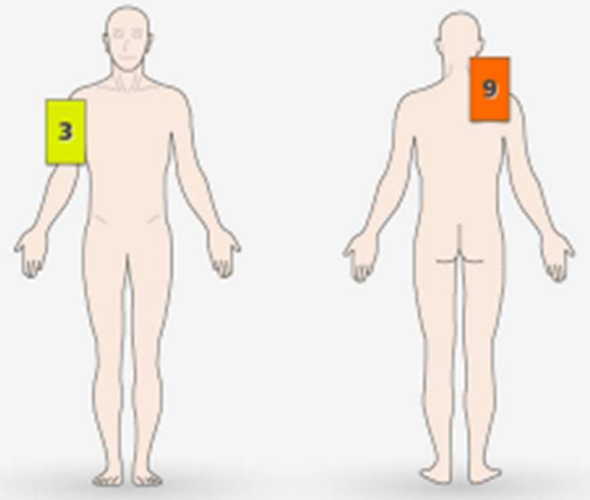

STOP

Screenshot 6 'Activities'

Instruction movie question 4

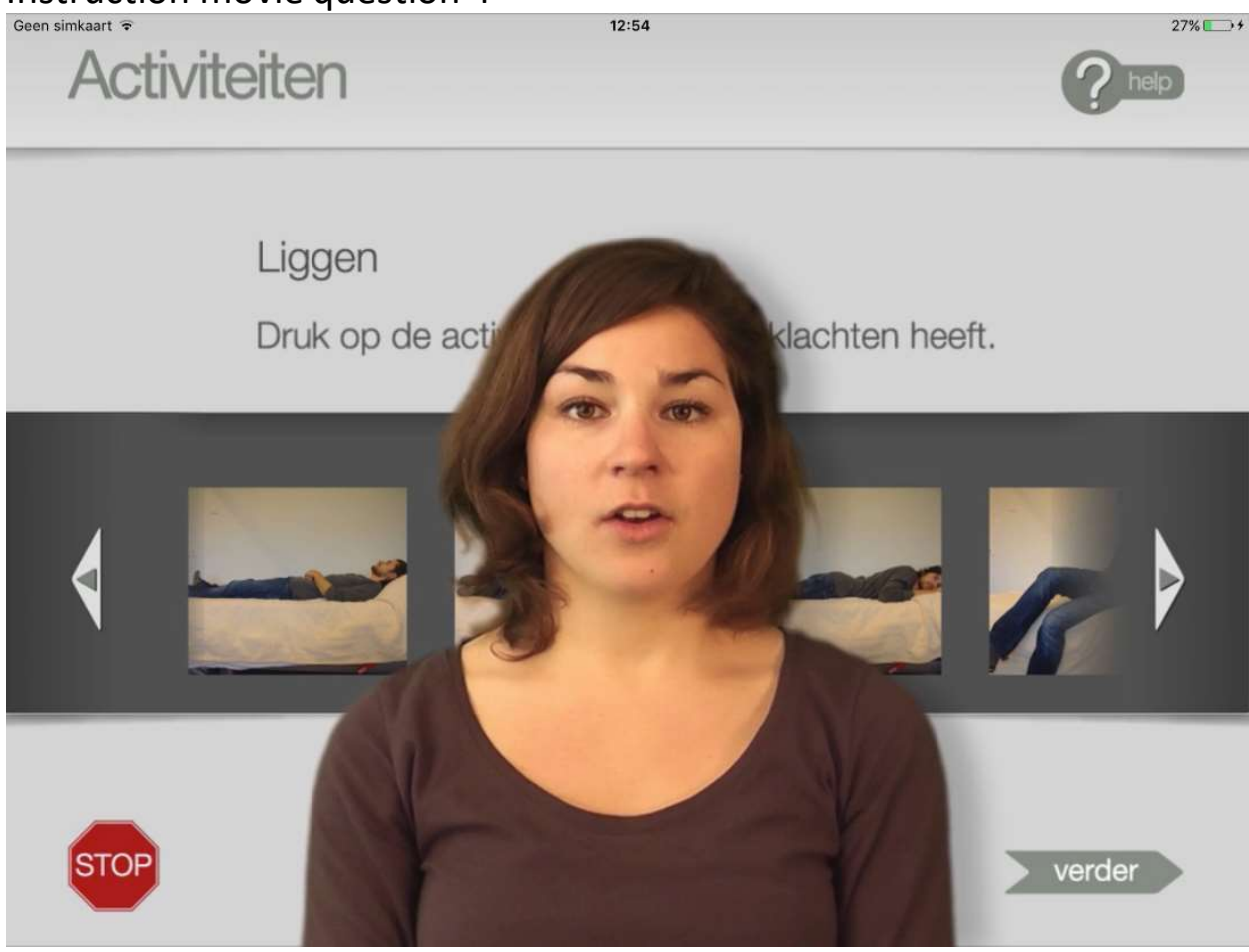




\section{Screenshot 7 Activity 'lying'}

Question 4: "Select the activities in which you are limited"

\section{Activiteiten}

\section{Liggen}

Druk op de activiteiten waarbij u klachten heeft.

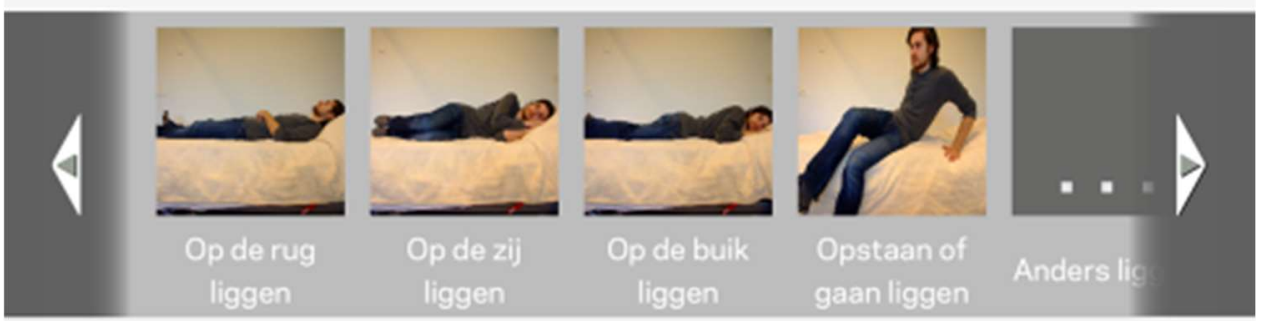

\section{Screenshot 8 'Overview activities'}

\section{Overview answers question 4:}

"On this screen you see all the activities that you selected in previous screens. These are the activities in which you are limited."

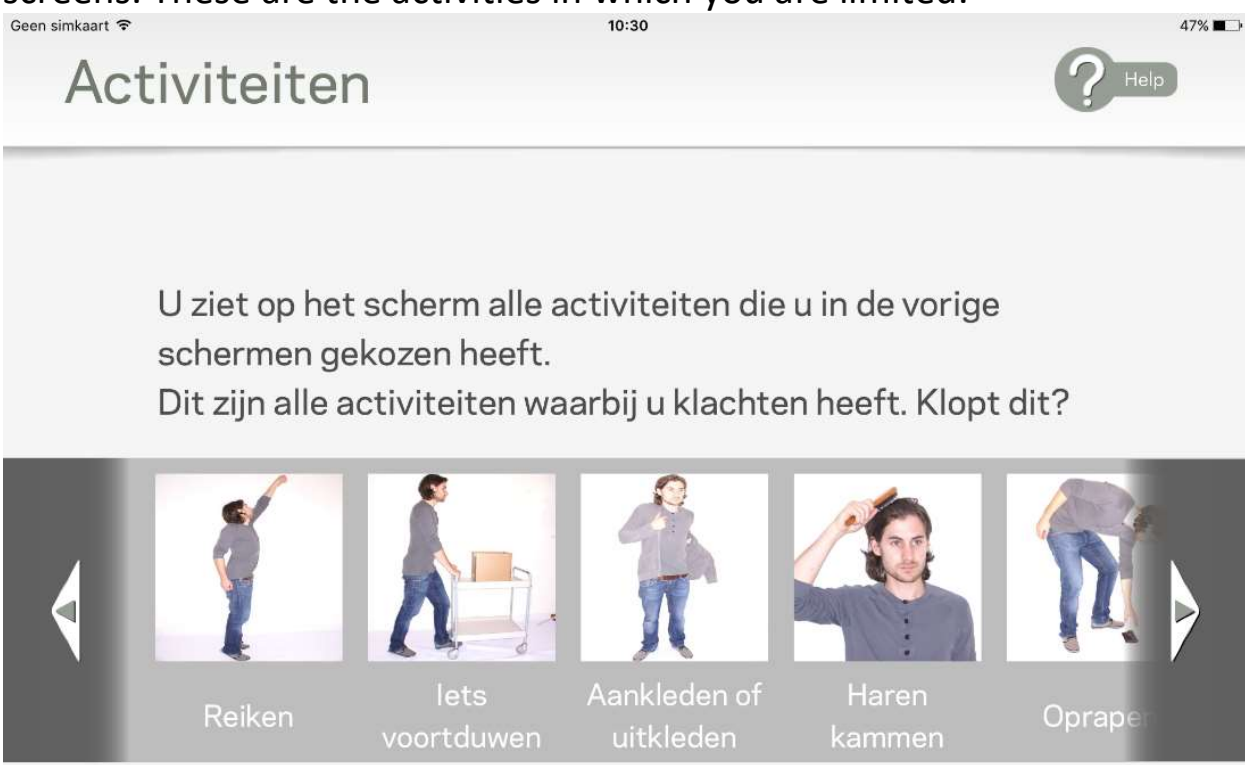


Screenshot 9 'Most important activities'

Question 5: "Select the three activities which are most important to you" Geen simkaart : 10:31

Belangrijkste activiteiten

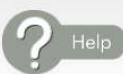

Kies de 3 activiteiten die $u$ het meest belangrijk vindt.

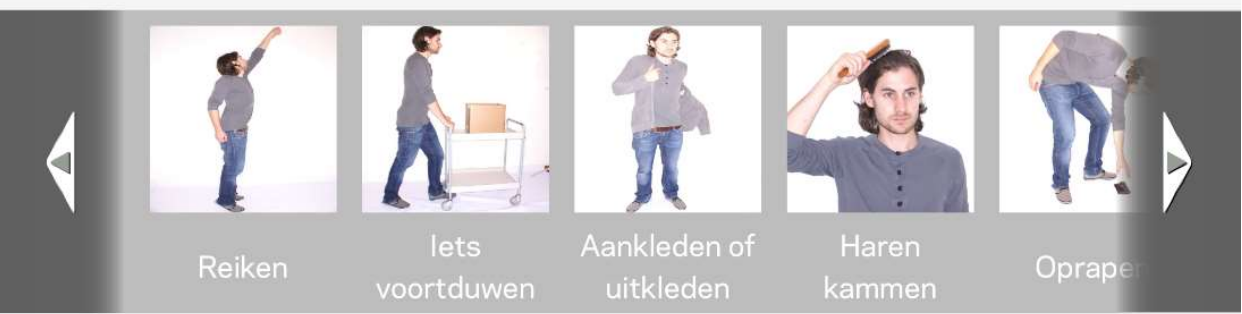

Screenshot 10 'overview most important activities'

Overview answers question 5:

"You chose these three activities. Is this correct?"

Geen simkaart

10:31

Belangrijkste activiteiten

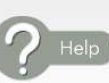

U koos deze 3 activiteiten. Klopt dit?

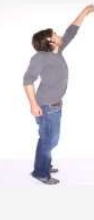

Reiken

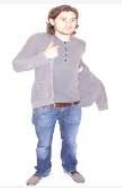

Aankleden of uitkleden

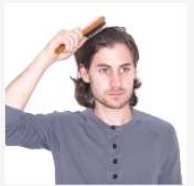

Haren kammen 
Screenshot 11 'Most important activity 1'

Question 6: "Select the activity which is most important to you" Geen simkaart ? $10: 32$

\section{Belangrijkste activiteit 1}

Kies de activiteit die het belangrijkst is voor $\mathrm{u}$.



Reiken

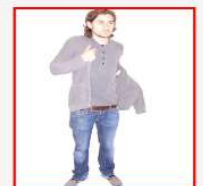

Aankleden of uitkleden

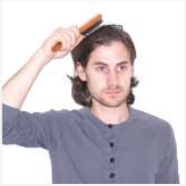

Haren kammen

Screenshot 12 'Most important activity 2'

Question 7: "Which of these two activities is still most important for you now?" Geen simkaart ? $46 \%$

Welke van deze twee activiteiten is nu voor u nog het belangrijkste?

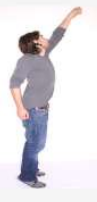

Reiken

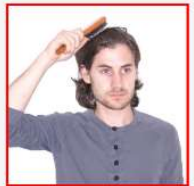

Haren kammen 


\section{Screenshot 13 'Effort activity 1'}

Question 8: "Rate the effort it takes to carry out this activity" Geen simkaart : 10:32

\section{Moeite activiteit 1}

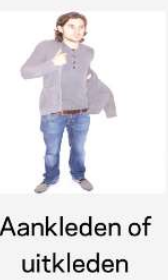

Geef op de balk aan hoeveel moeite deze activiteit u kost.

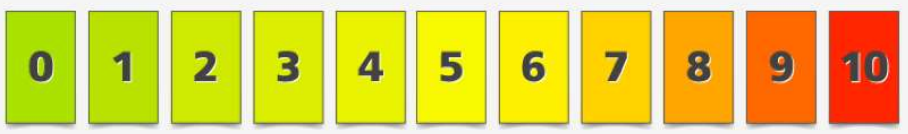

Screenshot 14 'overview most important activities and effort'

Overview answers question 6-8:

"On this screen you see the activities that are most important to you in order of most important to least important. Is this correct?" Geen simkaart = 10:33

$U$ ziet nu op het scherm de activiteiten die voor $u$ het belangrijkst zijn op volgorde van meest belangrijk naar minst belangrijk. Klopt dit?

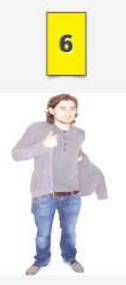

Aankleden of uitkleden

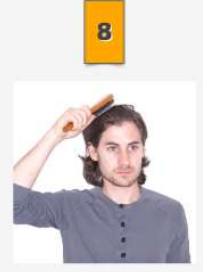

Haren kammen

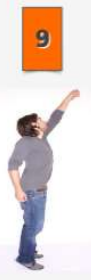

Reiken 
Screenshot 15 'overview all outcomes of the questionnaire' Overview answers total questionnaire:

"On the screen you see an overview of all your answers you provided until now." Geen simkaart :

$U$ ziet nu op het scherm een overzicht van alle antwoorden die $u$ tot nu toe gegeven heeft.
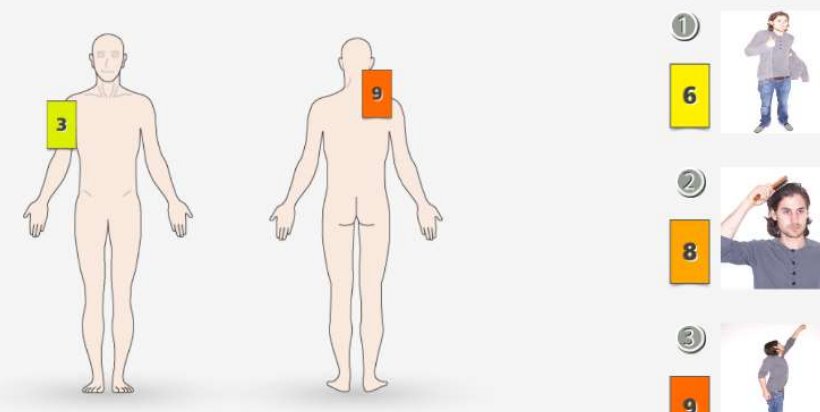

Aankleden of

uitkleden

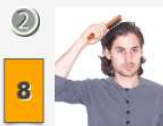

Haren kammen

(3) Reiken

Screenshot 16 'Thank you'

Closing movie

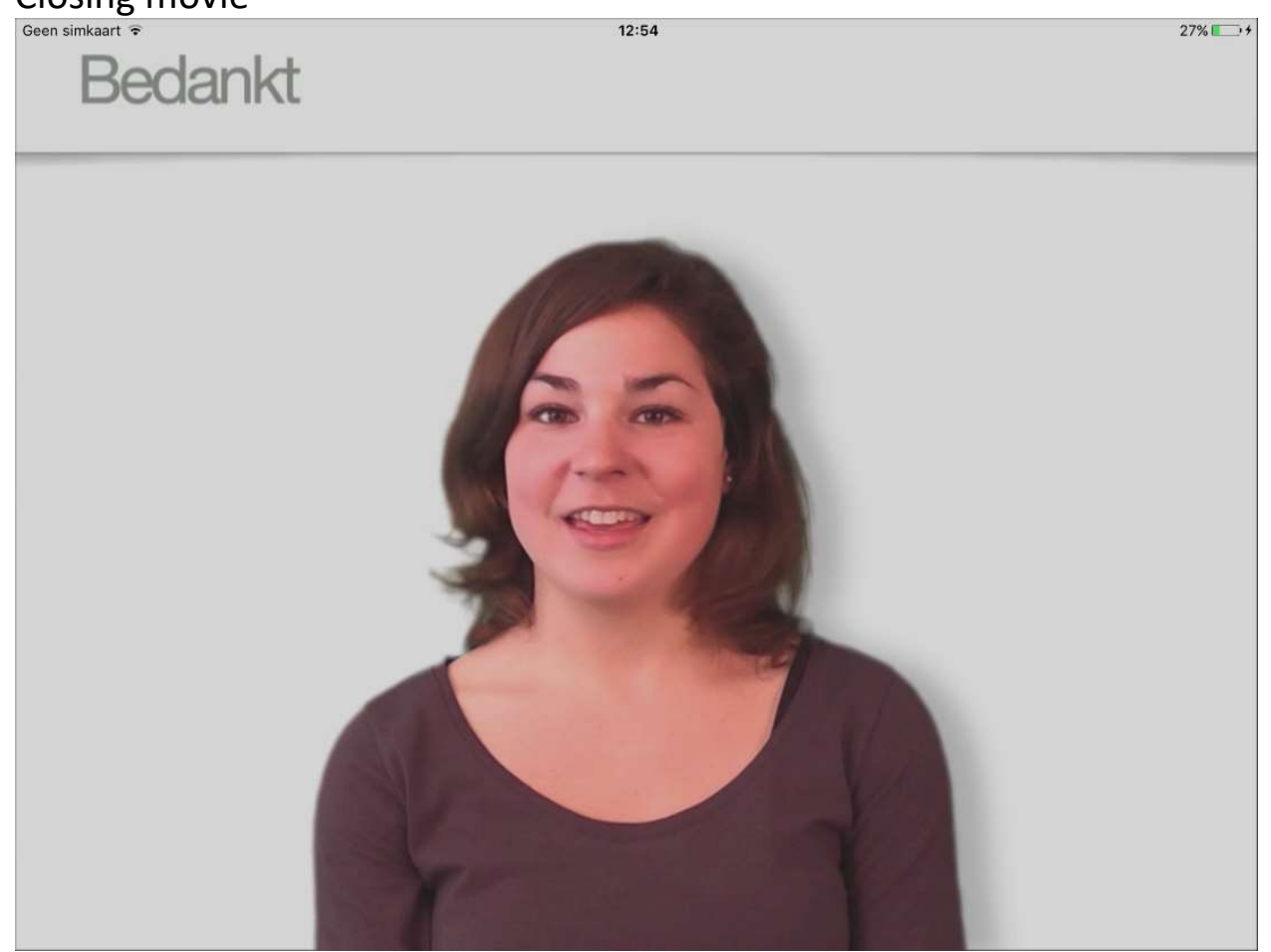

